SETH MOGLEN

\title{
Mourning Modernity
}

Literary Modernism and the Injuries of American Capitalism

STANFORD UNIVERSITY PRESS

STANFORD, CALIFOR N A 2007 
Stanford University Press

Stanford, California

(C) 2007 by the Board of Trustees of the Leland Stanford Junior University. All rights reserved.

No part of this book may be reproduced or transmitted in any form or by any means, electronic or mechanical, including photocopying and recording, or in any information storage or retrieval system without the prior written permission of Stanford University Press.

Library of Congress Cataloging-in-Publication Data

Moglen, Seth.

Mourning modernity : literary modernism and the injuries of American capitalism / Seth Moglen.

p. $\mathrm{cm}$.

Includes bibliographical references and index.

ISBN 978-o-8047-54I8-7 (alk. paper)-ISBN 978-o-8047-54I9-4 (pbk. : alk. paper)

I. American literature-2oth century-History and criticism.

2. Modernism (Literature)-United States. 3. Capitalism in literature.

4. Grief in literature. 5. Dos Passos, John, I896-1970. U.S.A.

6. United States-In literature. 7. Politics and literature-United

States-History-2oth century. 8. Literature and society-United StatesHistory-2oth century. I. Title.

$\mathrm{PS}_{22} 8 . \mathrm{M6}_{3} \mathrm{M}_{4} 2007$

$810.9^{\prime} 358-\mathrm{dc} 22$ 2007000338

Typeset by Thompson Type in Io/I4 Janson

Publication assistance for this book was provided by Lehigh University

"The Descent" was originally published in COLLECTED POEMS, by William Carlos Williams, I939-1962, VOLUME II, copyright (C1948, I962 by William Carlos Williams. Reprinted by permission of New Directions Publishing Corp.

"Hard Daddy"; "Letter to the Academy"; "Words Like Freedom"; "Harlem" were originally published in THE COLLECTED POEMS OF LANGSTON HUGHES by Langston Hughes. Reprinted by permission of Alfred A. Knopf, a division of Random House, Inc.

Part of Chapter I appeared as "On Mourning Social Injury" in Psychoanalysis, Culture, and Society, I0, no. 2 (Aug. 2005). Reprinted by permission of Palgrave Macmillan. 
To my mother, Helene, and to the memory of my father, Sig. 
